\title{
DIFFICULTIES IN WRITING NEWS ITEM EXPERIENCED BY STUDENTS OF A VOCATIONAL HIGH SCHOOL IN CIREBON
}

\author{
Syahfitri Anugerah Dewi ${ }^{1}$, Misdi $^{2}$ \\ Email:mybreath19@gmail.com ${ }^{1}$,misdirina@gmail.com² \\ MI Sain Suranenggal ${ }^{1}$, University of Swadaya Gunung Jati ${ }^{2}$ \\ Cirebon, Indonesia
}

\begin{abstract}
This study was qualitative research that used descriptive analysis. The present study aimed at investigating out the students' difficulties in writing news item and find out the most dominant difficulty in writing news item made by the eleventh graders of SMK Muhammadiyah Kedawung.in academic year of 2017/2018. The first research question was answered by taking 5 students at random to be analyzed to investigate students' ability in writing news item text. Students faced four types of difficulty such as agreement, preposition, and article. In agreement, it was found that all the difficulties are omitting and misusing the verbs and helping verbs of the sentence. Furthermore, to find the main difficulty in writing news item was to analyze 22 result of test. Based on the data analysis, punctuation was the most difficult aspects in writing proved by having 222 cases or $61 \%$ of cases. Spelling had 77 cases or $21 \%$ of cases. Proposition had 27 or $8 \%$ of cases on omitting prepositions. Agreement had 23 or $6 \%$ of cases on ignoring and misusing verbs of the sentences in their writings. Article had 15 or $4 \%$ of cases on ignoring the definite and indefinite article. In conclusion, it is suggested for English teachers to increase students' motivation in learning English, especially in writing news item text, and to make the students easier to understand and comprehend the material so the difficulties in grammar and mechanic can be decreased.
\end{abstract}

Keywords: writing difficulty, grammar, mechanic, news item text.

\section{INTRODUCTION}

English teaching indicates four abilities specifically: listening; reading; speaking; and writing. English also plays a vital role in education and students are likely to use it effectively. Many students are capable of understanding the language but most of them face the problem of developing their ideas effectively. According to Adas \& 
Bakir (2013) "the problem is the lack of both: the adequate stock of English vocabulary and creativity in writing." It means that among the basic skills writing is considered to be the most complex ability for second language learners especially in vocabulary building and lack of inspiration in writing.

Furthermore, according to Brown (2000:218) "writing is primarily a convention to record a speech and to emphasize lexical and grammatical features of language." In other words, writing is a process of making graphic symbols. It can be also said as forming and producing marks on a flat surface of some kind like paper or wall. In addition, writing is the ability to express the idea from the mind into written form and arrange it cohesively and coherently. Therefore, it can be meaningful. In writing, students firstly need to master good vocabulary and the creative way to put the words into a coherently meaningful passage. Henceforth, readers understand and get the meaning of the written form made by someone.

On the contrary side of it, Adas \& Bakir (2013) stated that "writing is the biggest challenge for many students." It is still a very tough mission for teachers to teach English creatively especially in writing. According to Byrne (1995:123) "learners make errors in writing when they try to do something with the language which they are not yet able to do." The learners have learnt something but perhaps they not comprehend well, have forgotten it or did not apply it. Therefore, it makes them difficult in writing as learning a foreign language is more difficult than learning a native language or learning a mother tongue. It may be caused by the complete difference of aspects and grammatical usage of the foreign language which should be comprehended by the learners, such as pronunciation, spelling, and the cultural background of the language. As foreign language, it makes English difficult in learning particularly in writing.

In the recent years, based on Indonesian curriculum, the students that have graduated from senior and vocational high school are expected to master the four language abilities such as writing, listening, reading and speaking, and in order to be incapable of doing communication well both in spoken and written ways. According to Indonesian curriculum, eleventh grade students have to be able to 
write some genres. One of them which is taught in eleventh grade is News Item text. News item is a text to give information the readers about events of the day. Sunardi (2015) stated that "the events should consider with newsworthy or important aspects." It means this genre is used to provide information of the events about daily news like business, sports, national politics, health and etc. News item is usually found in any written media in daily life for example, newspaper, magazine, tabloid and the internet. The text genre of news item is not the basic genre of text. It is a multi-generic text which is sometimes not explained in language books. Therefore, news item is not commonly discussed by experts.

Besides, Sunardi (2015) explained that "news item text enables to help people to get information from national up to world's events." News item is interesting to be analyzed because it is always used by people to inform other people and even as one of the information's sources. It becomes a reason why the researcher wanted to analyze genre text especially news item text.

In this case, the writer had conducted a pre-observation review at SMK Muhammadiyah Kedawung, it was found that many students still had difficulties in writing skill. The teacher also added that students make errors in grammar and how to write a text properly. Based on an informal interview with the English teacher, he indicated that students got difficulties in writing sentences properly like the tense, preposition, punctuation, pluralization, pronoun, spelling and etc. Meanwhile, the writer also has personal experience in teaching English. It was found that a lot of students have difficulties in writing. Mostly, difficulties are experienced by learners in writing news item text in using writing aspects for example in using agreement, tense, preposition, word-choice and punctuation. It may be caused by the lack of students' comprehension of writing aspects about how to use part of speech in writing. As Asassfeh (2013) classified that "some common grammatical errors are agreement, spelling, the use of article, prepositions, and logical connector." The subject-verb agreement is however the most frequent aspect which students make in writing. 
The study was attempted to investigate the students' difficulties in writing news item made by the eleventh graders of SMK Muhammadiyah Kedawung and the most dominant error in writing news item made by the eleventh graders of SMK Muhammadiyah Kedawung.

\section{Previous Study}

The problems and the writer's personal teaching experiences which were found in SMK Muhammadiyah Kedawung about difficulties in writing have the same line with some previously relevant researches about difficulties in writing. One of them is conducted by Emmariyana (2010). It was conducted in SMAN 1 Cigedug-Bogor. She took a title An Analysis on the Grammatical Errors in the Students' Writing (A Case Study of the First Year Students of "SMA Negeri 1 Cigudeg-Bogor"). This study is to find out the grammatical errors in writing. The study was a case study. It used a qualitative descriptive analysis. The respondents are 30 students. The technique of data collection which was used by her was test. After she did the research in SMA Negeri 1 Cigudeg-Bogor, she got the result of grammar errors made by the first year students of SMA Negeri 1 Cigudeg-Bogor in writing recount text. It was found that Tense was the highest category of difficulties by 19 students or $95 \%$, the second category was Spelling and Punctuation by 18 students or $90 \%$, the third category was Sentence Pattern by 17 students or $85 \%$, the forth category was Preposition by 7 students or $35 \%$, and the last category was Pronoun with 6 errors or $30 \%$. From the result of the research, it was suggested for the students to practice more in writing so that the students can avoid of producing kind of difficulties in their writing correctly.

The second research was conducted by Bahri and Sugeng (2014). This research study aims at: (1) finding out the forms of difficulties in writing in vocabulary and grammar of the second year students of SMP 1 Selong East Lombok West Nusa Tenggara in the school year 2008/2009, and (2) finding out the causal factors of difficulties in writing in vocabulary and grammar of the second year students of SMP 1 Selong East Lombok West Nusa Tenggara in the school year 2008/2009. The study was a case study. It used a qualitative 
positivistic descriptive approach. The participants consisted of 34 students. The main data were obtained from the 34 students' compositions. The other data were collected from observation, interviews, and recording. The results show that (1) eight most common errors of students' writing were: verb-tenses, articles, word forms, capital letters, punctuation, missing words, spelling, and prepositions; (2) verb-tense errors occupied the first rank (23.76\%), followed by article errors (20.85\%), and word form errors (10.62\%); (3) two kinds of direct factors caused the students to make errors in the writing skills were: negative interlanguage and intralingual transfers in the forms of adverb interference, copulative verb interference, word-order interference, tense-form interference, overgeneralization, ignorance of rule restriction, and incomplete application of rules; and (4) five sources of indirect factors caused the students to make errors in the writing skills were: students' low motivation, lack of use of media, low frequency of the writing instruction, lack of parents' support, and loose control of students' learning.

\section{METHODS}

In this study, the qualitative method is used to analyze data about students' main problem and ability to write news item text seen from organization and mechanic. In this qualitative study, data are collected, classified, presented, analyzed, and interpreted into a coherent description. This research is condacted at eleventh grade students of SMK Muhammadiyah Kedawung, the school is chosen because collecting feasibility the data and it is found there are some difficulties made by students in writing news item text. The participant of the study was XI TKR 1 consisting of 22 students.

In this study, the researcher chose writing test as an instrument. The students are to write a news item text to know students' ability in writing news item text. It requires the students to answer the first research question, then find out the major problems of students writing in writing news item text seen from aspects of writing such as organization and mechanic to answer second research question. 


\section{FINDINGS}

The first research question was revealed by taking 5 respondents randomly to be analyzed. It was purposed to get further information of the students' difficulties in writing news item made by the eleventh graders of SMK Muhammadiyah Kedawung. The research was focused on agreement, pronoun, preposition, article, spelling, and punctuation. Therefore, the writer analyzed students' writing based on those aspects.

In grammar, there were four aspects to be analyzed such as agreement, pronoun, preposition, and article. In agreement, it was found that all the difficulties are omitting and misusing the verbs and helping verbs of the sentence. These cases lead to agreement where the subject is singular and the verb needs to be singular too. Some of the cases of agreement also was about omitting a helping verb to the sentence like omitting 'did' (see appendix for full text) or any auxiliary verbs in the sentence. Knapp \& Watkins (2005:43) supports "verbs change their form to agree with their subjects".

In pronoun, it was found that students did not make any case on this aspect. All the students used the rules of pronoun correctly. In preposition, from the data analysis it was found that all the difficulties are omitting prepositions. Most of the cases were omitting 'of' to connect nouns to other particles of sentence. Meanwhile, some of the cases also were omitting 'by' the passive sentences. As Knapp \& Watkins (2005:61) stated that "prepositions locate nouns, pronouns and noun groups in time, space or circumstance".

In article, it was found that all the difficulties are omitting definite and indefinite articles. From the data analysis, some of the cases were not using 'a' as Sargeant (2007:44) "the article 'a' is used before singular nouns which begin with a consonant”. Other cases were about not applying definite article 'the' as Knapp \& Watkins (2005:44) define the rules of definite article "to the noun which is referring to a specific thing".

In punctuation, it was found that all the difficulties are omitting full stops, commas, and quotation marks and ignoring capitalization. Based on the data analysis, most of the cases were omitting full stops at the end of the sentences as Knapp \& Watkins (2005:61) argued that 
"full stops are used to mark the end of sentences". Some of the cases in punctuation was omitting and misusing comma. As Knapp \& Watkins (2005:48) stated that "commas are used within sentences to separate information into readable units and guide the reader as to the relationship between phrases and items in a series". The last case was ignoring capital letters. Based on the data analysis, mostly cases were ignoring capitalization at the beginning of sentences. To support, Knapp \& Watkins (2005:45) classified "rules of capitalization in writing a sentence".

In spelling, it was found that all the difficulties in spelling was omitting and substituting letters within a word. Additionally, Arndt and Foorman (2010) stated that "spelling is a linguistic skill; it is the visual representation of spoken language and relies on one's knowledge of the phonological, morphological, and orthographic structure of the English language". Therefore, students need to be clear in writing by using correct spelling.

Figure 1. Percentage of students' difficulties

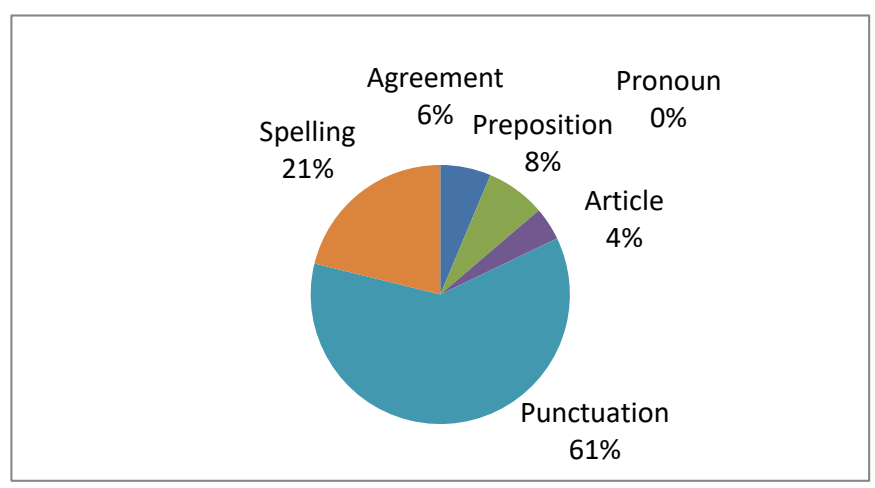

Furthermore, the writer analyzed the data from 22 students based the aspects of agreement, pronoun, preposition, article, spelling, and punctuation to find the most dominant difficulty in writing news item. The most dominant difficulty can be seen from aspect which had the highest number of cases.

In grammar, the result indicated that preposition had the highest quantity of cases than others. Based on the data analysis, it had 27 or 
$8 \%$ of cases on omitting prepositions. The second one was agreement. According to data analysis, agreement had 23 or 6\% of cases on ignoring and misusing verbs of the sentences in their writings. The third one was article. Based on the result, it had 15 or $4 \%$ of cases on ignoring the definite and indefinite article.

In mechanic, the result showed that punctuation had the highest amount of cases. Based on the data analysis, it had 222 cases or $61 \%$ of cases on ignoring punctuation marks and capitalization. The following one was spelling. Based on the data result, spelling had 77 cases or $21 \%$ of cases on omitting and substituting letters within a word.

\section{CONCLUSION}

Grammar as the language system plays important role in English learning. Therefore, as Faisal, M., \& Misdi, M. (2016) had investigated, teachers have to teach grammar using suitable method because they are an actor in the classroom who can control learning (Misdi, Hartini, Farijanti \& Wirabhakti, 2013).

\section{REFERENCES}

Adas, D. \& Bakir, A. (2013). Writing Difficulties and New Solutions: Blended Learning as an Approach to Improve Writing Abilities. Vol. 3 No. 9- International Journal of Humanities and Social Science.

Arndt, E. J. \& Foorman, B. R. (2010). Second Graders as Spellers: What Types of Errors Are They Making?. United States: Hammill Institute on Disabilities. Reprints and permission: http://www.sagepub.com/journalsPermissions.nav DOI: $10.1177 / 1534508410380135$.

Bahri, S. \& Bambang, S. (2008). Difficulties in Writing in Vocabulary and Grammar of The Second Year Students of SMPN I Selong East Lombok West Nusa Tenggara in The School Year 2008/2009. Yogyakarta: Yogyakarta State University.

Brown, H. D. (2000). Teaching by Principles. White Plains, New York: Prentice-Hall Inc.

Byrne, D. (1995). Teaching Writing Skill. United Kingdom: Longman Group UK Limited. 
Emmariyana, F. (2010). An Analysis On The Grammatical Errors In The Students' Writing. Jakarta, Indonesia: Unpublished Thesis from UIN Jakarta.

Faisal, M., \& Misdi, M. (2016). Investigating Classroom Instruction in Grammar Class Using Inductive Approach. ELT Perspective Jurnal Pendidikan Bahasa Inggris, 4(1).

Knapp, P. \& Watkins, M. (2005). Genre, Text, Grammar: Technologies for Teaching and Assessing Writing. Sydney, Australia: University of New South Wales Press Ltd.

Misdi, M., Hartini, N., Farijanti, D., \& Wirabhakti, A. (2013). Teacher-centred and Teacher Controlled Learning: a Postmodernism Perspective. ELT Perspective Jurnal Pendidikan Bahasa Inggris, 1(1).

Sargeant, H. (2007). Basic English Grammar, Book 1. United States: Saddleback Educational Publishing.

Uhing, V. G. S. (2015). A genre analysis of news item texts in the Jakarta Post and New York Times. Doctoral dissertation. Dian Nuswantoro University. 